\title{
Hunger for profit: how food delivery plattorms manage couriers in China
}

\author{
Jenny Chan* (1)
}

\begin{abstract}
How do food delivery platform firms, such as Meituan (operated by Tencent) and Ele.me (owned by Alibaba), manage couriers through service contracting rather than formal employment? How do couriers experience control and autonomy at work? Using observation and interviews, the author finds that a combination of data-driven surveillance systems and customer feedback mechanisms are incentivizing workers' efforts. Corporate utilization of both manual and emotional labor is critical to realizing profits. Individual freedom is framed in a way that crowdsourced couriers are not required to work a minimum amount of time. Flexibility enabled by the algorithmic management, however, cuts both ways. When there is less demand, the platform corporations automatically reduce their dependence on labor. With variable food orders and piece rates, workers' minimum earnings are not guaranteed. In the absence of Chinese legal protections over the fast-growing food delivery sector, informal workers are desperately struggling for livelihood. ${ }^{\bullet}$
\end{abstract}

Keywords: informal work, algorithmic management, emotional labor, food delivery workers, rural migrants, China.

\footnotetext{
* The Hong Kong Polytechnic University, Hong Kong, China.

$\checkmark$ This project is funded by the Early Career Scheme of the Research Grants Council of Hong Kong (RGC Project No. 25602517) and the Start-Up Research Fund of The Hong Kong Polytechnic University (PolyU Project No. P0000548).
} 


\section{Fome de lucro: como as plataformas de entrega de refeições gerenciam os entregadores na China}

\section{Resumo}

Como as empresas de plataforma de entrega de refeições, como Meituan (controlada pela Tencent) e Ele.me (que pertence à Alibaba), gerenciam os entregadores por meio de contratação de serviços em lugar de empregos formais? Como os entregadores percebem o controle e a autonomia no trabalho? Usando observação participante e entrevistas, a autora apurou que uma combinação de sistemas de vigilância, baseada em dados e mecanismos de feedback do cliente, é o que tem determinado os esforços dos trabalhadores. O uso corporativo do trabalho manual e emocional é crítico para a lucratividade dos serviços de encomenda de refeições. Para reduzir custos, as empresas não oferecem aos entregadores o salário necessário para reproduzir seu trabalho. A liberdade individual é configurada de forma a não obrigar os entregadores a trabalhar por um período mínimo de tempo. A flexibilidade possibilitada pelo gerenciamento algorítmico, no entanto, funciona em ambos os sentidos. Quando há menos demanda, as empresas de plataforma reduzem automaticamente sua dependência de mão de obra. Com tarifas variáveis por pedido, os trabalhadores não têm assegurado um rendimento mínimo que atenda o padrão de vida médio local. Esta pesquisa contribui para uma compreensão mais aprofundada dos desequilíbrios de poder entre trabalhadores, empresas de aplicativos e clientes na economia de plataforma orientada a serviços da China. Também estimula o debate sobre a informalidade do trabalho no que concerne à responsabilidade das empresas e do governo.

Palavras-chave: gestão algorítmica, trabalho emocional, informalidade, economia de plataforma, serviço de entrega de refeições, China.

\section{Introduction}

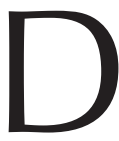
igital platform operators are intermediaries in the online marketplace. UberEats, Deliveroo and Foodpanda generate profits from restaurants, consumers and couriers by providing food delivery services through their platforms. Early research is skewed towards certain Western businesses, leaving out Chinese platforms that recruit significantly more workers and reach out far more consumers across different walks of life (Heeks, 2017). In 2018, over 440 million people in China were active 
monthly users of takeaway apps, generating revenues of 471 billion yuan (State Information Center, 2019, p. 22; 2020, p. 10). Two delivery platforms, Meituan and Ele.me, dominate the domestic market, while Chinese logistics giant SF Express has branched out into delivering food since May 2020 amid the coronavirus pandemic. With rising demands for delivery services, over seven million couriers have joined the informal labor force (Wang, 2021).

How do food platform corporations manage couriers when they are not their employees? How do couriers experience control and autonomy in their work process? Wu and his colleagues (2019, p. 576) observe that normative expressions such as share, task, help, and service are now frequently used by businesses, and governments as well, instead of more clearly defined terms like work, job, and employee. In this discourse, relations of production are obscured. As this research will show, however, the power dynamic between "service providers" (workers) and "users" (consumers) is highly imbalanced. Platform firms, in a tacit partnership with the Chinese state, have sought to boost growth while informalizing labor relations.

The data of this empirical study is primarily drawn from field research, which is supplemented with publications by academics, companies and the government. The author shadowed food-delivery couriers to learn about their working lives in Beijing during intense trips between 2017 and 2018. Thereafter, she engaged in online discussions with a core group of couriers to learn about their individual and collective tactics to make a better living. In the following, Section Two presents the analytical framework by drawing insights from labor process theory, sociology of emotional labor studies, and informalization of work in the context of a platform economy. Section Three describes the first-hand, qualitative data collection methods. Section Four analyzes the recruitment and management strategies, as well as the tensions stemming from corporate control and limited autonomy, as unveiled by workers' vivid testimonies. The concluding section reflects on the precarization of platform-mediated labor as structured by tech companies and the Chinese state. 


\section{Analytical framework}

\section{Management techniques and labor control strategies}

In Marxist formulation, capitalists aim to control time and motion of workers to extract surplus value in the production process. This encompasses a wide range of rules and regulations in governing the activities and use of time by employees. With the application of the Taylorist principle of "scientific management," work is further broken down into minute details and repetitive segments to raise productivity. The lengthening of a workday, coupled with coercive measures to intensify efforts, can be physically exhausting, mind numbing and alienating. In Labor and monopoly capital, Harry Braverman ([1974] 1998) analyzes the ascendance of managerial power and the increasing separation between manual and mental labor in industrial and clerical work settings.

Labor management is not simply a technical problem but a matter of class conflict. From despotic to hegemonic control, Michael Burawoy (1985) highlights the legislation of labor protections and the set-up of worker representative mechanisms in the transformation of law, economy and society. With access to some welfare support, workers' dependence on one single employer for a wage is to some extent reduced. A more sophisticated approach is then required of management to ensure employee compliance. On the shopfloor, the introduction of productivity enhancing make-out "games" is thereby intended to motivate workers to compete with each other for tangible gains. Such granting of a certain degree of employee self-control helps secure participation in the work process. Workers give consent to their own exploitation (Burawoy, 1979). This sociological inquiry inspires multidisciplinary investigations of the links between labor subjectivity and disciplinary structures.

In the contemporary context of digital platform-based work, the rise of algorithmic management has supplemented, if not replaced, direct control by managers on-the-spot. Software applications and mobile technologies 
"allocate, optimize, and evaluate work" to improve cost effectiveness (Lee et al. 2015, p. 1603). Corporate platforms collect a wide array of data to keep track of the gig work, also known as "microworks," being undertaken by workers in real-time. These "platform workers" are coordinated through computing programs and online connectivity, without "the physical presence of someone" breathing down their neck (Griesbach et al. 2019, p. 11). The fulfilment of specific work demands, or the failure, will be conveyed to the centralized electronic system. In this sense, the absence of a human manager - replaced by an "algorithmic boss" - does not lessen the degree of corporate control (Ivanova et al., 2018).

For motivating workers to meet or exceed the targets, platform companies have introduced "game elements" in the labor process. This process of gamification, accompanied by prizes and rewards, has led to higher productivity rates (Woodcock; Johnson, 2018; Veen et al., 2020). As for workers, they need to navigate digital and physical spaces to complete the "tasks" within the delivery time limit.

Studies on ride-sharing platform firms such as Uber and Lyft show that they commonly require drivers to score "a high acceptance rate" of requests over a certain period of performance evaluation (Rosenblat; Stark, 2016, p. 3761). The acceptance rate is calculated by the number of accepted rides divided by the total number of automated assignments sent to the driver. With a high rate of completed rides, the driver will be rewarded both symbolically and materially. Frequent rejection of undesirable or uneconomical online assignments will result in suspension, or even deactivation, of the user account, and there is basically no way to dispute the firing or "challenge the data that has been collected" (Woodcock, 2020, p. 88). Yet, the clash of corporate monitoring and workers' quest for free time as well as self-direction at work continues.

\section{The monitoring of emotional labor in service work}

Meal delivery is about servicing. Whether it is a brief encounter involving workers and customers, or longer-term relationship building by 
means of affective commitments, workers' efforts in producing a desired state of mind in the service recipients are elicited and monitored. Arlie Hochschild ([1983] 2003) illustrates the corporate technique of deskilling among frontline service workers, who are instructed to serve customers in accordance with a set of organization-defined emotional rules and quality standards. For male as well as female workers, doing "emotional labor" entails "the management of feeling to create a publicly observable facial and bodily display" in exchange for a wage (Hochschild, [1983] 2003, p. 7). Thus, management intervenes in workers' minds and hearts, as much as hands and feet, to generate a profit.

Companies actively solicit consumer feedback to discipline workers' attitudes and behavior, evaluate job performance and improve social interaction to enhance competitiveness. Linda Fuller and Vicki Smith (1991, p. 11) conclude that "consumers' reports broaden managerial power, augmenting it with customer power." This is a three-way relationship between management, workers and consumers in the context of service production and consumption. In numerous corporate training programs, workers are equipped with scripting of speech, using body language to convey the intended message or making a professional presentation to accomplish their jobs (Leidner, 1993; Wharton, 2009).

To save investments in human resources, platform firms have shifted the customer service responsibility to workers. Falling short of customer expectations, workers - who are not algorithms at the backend - are clearly visible and often targeted for poor service (Lee et al., 2015). In big cities, where traffic jams are commonplace, for example, drivers of Didi (that acquired Uber in China) must rely heavily on their own judgement to tame customers' anger in both online and offline communications. They often attend closely to passengers' preferences, such as their liking for music and air-conditioning during the ride, thus winning favorable evaluation $(\mathrm{Wu}$ et al., 2019). This kind of self-investment in emotional work - managing their own feelings and customers' emotions - is making interactive service work possible. 
In a work performance review, guidelines on what level of service is requisite for each star rating are rather vague (Rosenblat; Stark, 2016, p. 3775). Algorithmic metrics incorporate customer supervision to sustain and further improve quality service. Min Kyung Lee and her coauthors (2015) point out that metrics collected by platform algorithms are not always objective or fair to the worker in question. In the case of ride-riding, passengers who are late for a flight may not positively appraise the Uber driver or the riding experience, even when it has nothing to do the driver's performance. So, what counts as high quality service?

Spatiotemporal challenges are formidable in the real world, where there are often delays and disruptions due to traffic problems, bad weather or other human factors (Sun, 2019; Chen; Sun 2020; Wu; Zheng, 2020). Customers' rating - a key dimension of emotional labor - is integral to a larger surveillance system of the platform economy. In this light, food delivery workers are not simply "users of a digital medium" but workers subjected to a capitalist relation of production (Gandini, 2019, p. 1041).

\section{Freedom and autonomy of crowdsourced workers}

Crowdsourced workers are independent contractors who enjoy some freedom to decide when and where to work. In the United States, for example, Instacart (a large grocery delivery platform) shoppers explained how they cope with their family care responsibilities while doing part-time delivery work of their own choice on the weekdays or weekends (Griesbach et al., 2019; Milkman et al., 2021). They made good use of their shopping and meal preparation skills to help the elderly and dual-earner couples in the local community. In Australia, where Deliveroo and UberEats are dominant players, researchers (Barratt et al., 2020) found that male and female immigrant workers, as well as international students with working holiday visas, similarly took advantage of the informal work opportunities and flexible hours to make money. Multi-apping - working on multiple 
platforms simultaneously to get more and better orders - may increase individual workers' earnings.

Platform firms strive to set work rules to ensure the satisfaction of customer needs anywhere, anytime. In a closer look, the lived experience of entrepreneurial agency and personal autonomy within the platforms' operations is restrained. Couriers' rights of employment are unprotected by law. Trebor Scholz (2017, p. 13) argues that the rise of a platform-mediated labor regime is "instrumental in the process of dissolving direct employment, thereby creating low-wage futures for millions of people." In China, outside of the formal employment system, hundreds of millions of workers - most of them rural migrants - are not entitled to social insurance benefits, which are jointly administered by local governments, employers and employees (Lee, 2019). In the food-delivery sector, crowdsourced workers must also compete head on with those who are hired by franchisees or agencies. Food-delivery station managers often assign orders to their own team in the hope to improve labor retention and generate greater revenues (Lei, 2021; Liu; Friedman, 2021). As a result, crowdsourced workers are confronting tremendous pressure to survive.

In recent years, activist workers have been facing an uphill battle to fight for decent pay and social security, even when self-organizations like AlgorithmWatch, Transnational Federation of Couriers, and The Rebel Roo have gained some traction through the Justice4Couriers campaigns in Europe (Cant; Mogno, 2020). In China, food-delivery riders similarly staged collective actions to demand higher pay through online coordination, sometimes winning partial victories. Instead of causing huge disruptions to traffic to get public attention, the protesters kept a low profile to bargain with management, thus averting a clampdown by the stability-obsessed authorities (Liu; Friedman, 2021). These worker-led protests were often localized and short-lived, with platform management holding onto power with their institutional resilience (Sun; Chen, 2021).

Building a conceptual framework of corporate dominance and management control, emotional labor demands in interactive service work, 
and the informality of crowdsourced workers, this research examines the working conditions and coping strategies of Chinese male rural migrants in food delivery service. Rural migrants, restricted by the household registration policy, do not enjoy legal residency in the cities where they work and live (Gallagher, 2020). This means that these internal migrants have no access to urban welfare benefits such as subsidized healthcare in public hospitals or local pensions. In this tiered-citizenship structure, Chinese migrant food-delivery workers are more vulnerable than their city counterparts to making a decent living.

\section{Research method}

Beijing, the capital of China, has grown to a global city with 22 million people, including internal migrants from all over the country. With the penetration of mobile technologies and internet networks, digital platformbased work opportunities are prevalent. Between fall 2017 and summer 2018, the author and her team conducted semi-structured interviews with 32 food delivery workers through multiple extended research trips. The informants were male rural migrants, ranging from 19 to 48 years of age. All were working full-time on at least one delivery platform for their primary source of income. Home visits, arranged by friends and colleagues, took place at their rental rooms during off-work hours. The other meetings were set up at dining places where they frequently received orders. The interviews focused on work history, experience of platform-based work including but not limited to meal delivery, and comparison to previous wage employment if appropriate.

During the long workday from early morning to late night, the author sat at the courier's back on the motorbike to pick up the takeout orders from restaurants. She was repeatedly assured that "we both would be very safe" on the highway and at the crossroads heading to the destination. Sometimes, she offered little assistance en route, like rushing to press the button for a lift and carrying the drinks and desserts. She learned that the courier freely selected from the online platform "the district" where he wanted to deliver. 
The preferred working areas were concentrated in tourist and commercial sites and the surroundings, such as Galaxy $\mathrm{SOHO}$ the mega shopping mall and offices located at the heart of the city.

Supplementary to interview scripts and field notes, the author carried out a documentary analysis of company policies through the publicly available sources. She also maintained contacts with key interviewees via social media amid the COVID-19 pandemic. The identifying details were removed to ensure anonymity.

\section{Findings}

\section{Recruiting couriers through the food-delivery app}

Food-delivery platforms do not screen applicants based on their educational credentials or previous job experience. This "open door" recruitment policy is intended to streamline administration and to increase labor supply at a low cost. Indeed, Meituan and Ele.me - the duopoly in the takeout market - welcome new blood through referrals by friends and families. Interviewees shared that it is a common pattern of "fellow villager brings fellow villager" when entering an unfamiliar terrain like platform work in the city. As long as they are able to handle the minimal start-up costs, they "get the job" through signing into the app.

A delivery worker, who is deemed as an owner-operator, has to buy an e-bike, a delivery bag, a safety hat, and waterproof and windproof clothing to get ready to work. It is also necessary to have a smartphone to open a user account. After accepting the "terms of service" agreement with the platform, the "self-employed" courier is eligible to take an order. The terms of agreement specify that the courier is an independent service provider. By accepting an order, he is individually held accountable for collecting the item, deciding the route and delivering the item to the customer quickly.

To begin with, a courier downloads a free food-delivery app onto a smartphone to understand how it works. He takes a few orders, one order 
at a time, to do part-time before transitioning to taking multiple orders on a full-time mode. In an interview, Zhang commented on his selection of "the favorite platform" in the first month of work:

Before the mergers of Baidu Deliveries and Ele.me in 2017, I had done quite a lot of different platforms to find out which platform is more suitable because every platform looked similar but in practice, actually, they have some differences. Meituan has been expanding fast as the platform dishes out cash to get new delivery drivers.

The differences mainly refer to variable piece rates per successful delivery and additional prizes and bonuses offered by the platforms. Before learning the specifics, a core concern to Zhang is "getting paid for one's labor effort."

Having a bitter taste of non-payment of wages in construction and other casual jobs, Zhang needs to secure his pay on time. Working for the delivery platform, this time, he is able to withdraw earnings from the application at any time and receive the amount via autopay through his bank account within 48 hours. This sense of security - not about the lump sum, which is never certain or fixed; but about "getting paid" for his work - is positive. Indeed, the company highlights that most important point: "Freely accept orders, flexibly settle your account."

Zhang bought a second-hand e-bike because a foot-pedal bike would be too slow to accomplish the fast delivery tasks. He borrowed some money as needed. In the first month of riding for a platform, he recalled:

I soon realize that I need a proper transportation vehicle. If you are just riding an ofo, a shared bicycle, how much money can you make? The platform doesn't provide you with the work tool. When I first started working this, I didn't have any money to buy an e-bike. I did runs for half a month riding an ofo all day long, earned 100-yuan day and was so tired, my legs were so painful. It was tough and I couldn't stand it.

Delivery work requires physical fitness and high speed. After having got the e-bike, Zhang logged in very long working hours in the hope to make more money: 
Yes, I choose how much I want to work. Last month I worked for 31 days straight, didn't rest. The number of orders at the moment are fewer, to earn more money then, I can't rest.

Zhang does not have any paid leave. A normal five-day work week as stipulated in the Chinese Labor Law does not apply to him, who is not recognized as an employee. Those who are willing to work for a full month, like Zhang, without a single rest day, greatly help ensure low-cost service delivery around the clock.

In recruitment campaigns, platform corporations invite a potential courier to become a "delivery brother," giving the suggestion of a young man who is agile, fast and strong. One advertisement showcases Yang Yang, a Shanghai pop star born in 1991, as the cheerful deliveryman catering for the needs of urban consumers. Marketing to disadvantaged but ambitious rural migrants as micro-entrepreneurs, Meituan uses aspirational corporate messages such as: "High incomes, many orders, good security." Moreover, "you're the one who can surpass the white-collar workers!" A dream of upward social mobility is dreamt of. The advertisement publicizes that the earnings could be as high as 13,000 yuan a month; and there is no upper ceiling! Putting the figure in perspective, a monthly salary of approximately 10,000 yuan closes in on an average salary for Beijing residents. Low-end restaurant delivery employees make only 3,000 yuan to 4,000 yuan a month.

As for the older cohorts of rural migrants who lack formal education or credentials, they probably have few options better than platform labor. After many years of migratory work, they are familiar with the local conditions, constraints and opportunities of work. Zhang is thinking about his family in the village, having "elders above me and minors below." He is desperate to earn as much money as possible in Beijing before "going home."

Echoing Zhang, Wang explains his thought in an interview: "Work more, earn more;" "No pain, no gain." Working longer hours and waking up earlier to begin delivering are the "good practices." In Wang's words: 
The more you put in, the more you get back, like those who wake up early in the morning when it's getting light at 6am in the morning, and work all the way through to the mid-night, every day they can earn 300 to 400 yuan. Some others, in one day, only earn 100 to 200 yuan. Why? They don't wake up in the morning, and in the evening always go home sooner. If you don't work, then you can't earn money, right?

Crowdsourced workers like Zhang and Wang are promised high pay, but the realization of the promise, if not an empty one, rests on their own bodies. No paid leaves. No pensions. No health care benefits. The only pay for their work comes from a satisfactory delivery. The waiting time for a takeout order, occasionally up to an hour, is not counted as "work time" and henceforth not paid at all.

\section{Motivating couriers to hit targets through algorithmic management}

A faceless "algorithmic boss" mobilizes and directs the workforce to fulfil the tasks. Uber drivers, for example, are incentivized to chase algorithmically-derived "surge pricing" at times of high demand to boost their income (Rosenblat; Stark, 2016). Similarly, food-delivery couriers are motivated to hit targets regulated by the platforms. In the setting of platformmediated work, the pricing is subject to the supply of orders and number of couriers within reasonable distance who are able to quickly complete an order. Couriers will pick an order by scrolling through a list of available orders in their area, which they are eligible to deliver. They compete with each another to "grab the order" through the platform application. It is important to refresh the list of deliveries, which carries dynamically changing payment terms, that is, they change frequently depending on the latest calculations of supply and demand locally.

The interviewees are not informed of the number of couriers they are competing with but observe the lineup of couriers on the road and outside of the restaurants. The downward pressure of piece rates over the years, however, is strongly felt. Chen, a 33-year-old migrant worker from rural Hebei, comments on the low price: 
In work there are too many food-delivery couriers now. Before, when you had an order sent out by the system and no one wanted it, they would increase the price to 10 yuan. Then, after another five minutes, if still no one wanted it, they would go up to 15 yuan, finally 20 yuan. Now, an order comes out, and it is gone in one second. There are too many couriers.

Chen, addressing to fellow mates on a blog, called for the defense of the "bottom line" by adhering to a minimum delivery price of 4.5 yuan per order, plus an addition of 2 yuan per kilometer in completing the ride. Falling below this floor standard, in his view, one should not accept the order. Forging a collective response to upholding the rock bottom line of pricing seems to be very challenging if not impossible. Chen continues:

I've just seen that an order was 8 yuan. No more. It went down to 7 yuan, 6 yuan, and further to merely 5 yuan. It is still being grabbed right away. The price has been driven lower and lower. Now it feels like an order comes out and then it's gone.

Couriers are "operating within a process controlled by a black box" while waiting for work (Cant; Mogno, 2020, p. 408). Companies retain business data and the algorithms set prices per delivery. Under information asymmetry, platform workers cannot fully comprehend the ever-changing prices of the orders. To grab something online, no matter what, is necessary for survival. Chen concludes:

The platform is more and more about artificial intelligence. The online system doesn't care how many people are working. It only cares if the orders can get out quickly. Who grabs them? Who can't get any? What is fair or unfair to couriers? If you can grab one, that's good; after all, that's good for the platform.

Even when the price per delivery is very bad, the pressure to take it is strong. The digital platform is an interface linking customers, workers and restaurants in the market. It does not provide workers with minimum hourly or monthly wages. 
In a low voice, Chen confided that his earnings had been slashed by "a half," from a peak of close to 10,000 yuan a month to some 5,000 yuan a month at the time of interview. He gets prepared to work anytime while staying online. Importantly, he adapts his scheduling to try to match spikes in demand, such as mealtimes and special festivals.

Outside of the busy timeslots, couriers are rewarded for taking orders that are less favorable; in this way, consumer demands can be better met. The app's set targets for couriers and the rewards on offer for meeting them are carefully designed to interweave with couriers' ambitions to hit their personal income targets. During 2017 and 2018, one food-delivery platform set up a four-level bonus system, ranking from the top: God-like courier (a top-up of 1.5 yuan per delivery), Saint-like courier (a top-up of 1.2 yuan per delivery), Diamond courier (a top-up of 1 yuan per delivery) and Black Gold courier (a top-up of 0.8 yuan per delivery). The total number of completed orders is the main basis for algorithmic ranking. The bonus is wiped clean at the start of every time period (for example, start of the month), and the courier will start freshly accumulating rewards. This widely used gamification mechanism is designed to instill positive reinforcement and commitment to work. In this environment, "demarcation between work and leisure time" is increasingly blurred as couriers are pushed to take as many orders as possible after getting online (Sun, 2019, p. 315).

The bonus and status ranking system incentivizes the fastest couriers to gauge themselves against other couriers. Many are tempted to "stack multiple orders at any given moment in order to maximize their income" ( $\mathrm{Wu}$; Zheng, 2020, p. 10). Qiang, a 32-year-old migrant from rural Guangdong, clearly explains the challenges in spatiotemporal terms:

The first most important thing is to not have to search for a place. Get the address and go! Directly hand over the ordered item. A tired body actually isn't too tired. It's tiring in your brain. If you grab an order to this area, you have to think for a second, you can't just take one order, you usually have to take quite a few different orders. This area has what places, in this area there are a few more orders, or that area or that area where there are more orders, you have to think all about, you yourself have to make all of that work. 
Couriers calculate the amount of time they use, every minute and every second, to complete deliveries. Taking two orders simultaneously from the same restaurant or the restaurant next door and then delivering them to places that are not far apart are labor-saving options. Efficiency is life. After all, prepared meals are perishable products, hot food gets cold quickly.

Platform algorithms estimate the allowable time for delivery on the distance between the customer and the restaurant, not the reference to the specific location of the couriers. Tong, a 47-year-old Anhui native, tries very hard to train himself to work better and faster:

I learn the geographical location of each place, where the collection places and the routes are. The GPS [Global Positional System] does not display side roads or shortcuts that can significantly shorten the ride.

Like Tong, Bai is very diligent and has learned the tricks of the trade:

As soon as you see the order, you know how long to get there, even which entrance you can use in that neighborhood. Is the building closer to east or west gate? That gate is more convenient, you know it all. Experience matters. To get experience requires a period of time searching and accumulating. How to manage the routes, having multiple jobs, how can you manage the sequence - this is all experience.

As couriers accumulate more experience and acquire practical navigation knowledge, the algorithmic system also upgrades itself. It resets and reduces the time needed by taking into consideration the couriers' shortcut, thus revamping food orders and intensifying labor efforts.

Some university dormitories and residential areas do not allow couriers or any other unauthorized persons to enter. High-end dining places likewise rule that couriers - the sweating and smelling bodies - must wait outside for the takeout orders. A social class boundary exists. As Julietta Hua and Kasturi Ray (2018) observe in American cities, taxi and ride-hailing drivers - particularly the non-white immigrant men - are unwelcomed to use restrooms in hotels or restaurants. Their working-class status and ethnic origins do not earn them respect. 
Bai, a 35-year-old rural migrant, endures social inequalities and multiple hardships by lengthening the working day and shortening his rest time. He shares his corporeal experience:

Sun, wind, rain or shine you have to be out there working. At this time, the weather is not too bad, everyone of course likes to be outside delivering, and the price per order goes down accordingly. It's in the winter when it's freezing, or in the hot summer, that you have to continue to work very hard. I get a subsidy for the extreme hot and cold, that keeps me going particularly when the weather is really hot or really cold.

Bai adds that strong will and even risk taking is needed to beat time, thus hitting the goals under extreme weather conditions:

The system limits the time and it will always be very short. When you have multiple tasks at the same time, if you don't cross red lights and drive in the wrong direction [on a one-way street] it's very difficult to complete on time. The food-delivery sector is striving after speed, so the time given to drivers is very short.

It is distressful to wait and observe the cost of a late delivery, incurring fines and demotions on the leaderboard. Couriers are not permitted to reject an order once it has been grabbed and will have to spend time waiting during collection at the restaurant. Zhu, a 45-year-old Hebei native, sighs:

Actually, at every moment we are rushing around to make up time, but it's the system that gives you the time. You can never outrun the system.

The "weakest" couriers have no choice but quit. This "survival of the fittest" ideology obscures the numerous contextual factors that come in the way of achieving timely delivery. In the algorithmic world of labor management, customers are delegated power to co-manage service production. Positive customer comments or feedback will contribute to bonuses. By contrast, complaints will result in fines and penalties. Under this situation, workers learn to be highly responsive to demands, which goes beyond fast delivery per se. 


\section{Mobilizing customers to enhance service quality}

Deference and subordination to customers is built into a good service. To be courteous toward a rude customer requires emotional work. Voiceto-voice and face-to-face contacts, such as a sincere apology for failing to meet the expectations, is essential to cool things down. Low-level workers, compared to professionals and expert service providers, lack a "status shield" in performing services (Hochschild, [1983] 2003). They must remind themselves to appropriately handle customers' needs and feelings.

Meituan and Ele.me pledge to adhere to the highest safety standards to ensure customers remain safe while having a delightful consumption experience. When demand for meal delivery surged amid the coronavirus disease and lockdown, during much of 2020 and 2021, couriers were running out of breath to continue home deliveries. However, they received complaints for delayed and bad customer services.

Data-driven surveillance systems and customer feedback mechanisms shape workers' behavior. With technological advancement, the app allows customers to track the location of the couriers throughout the journey from the collection of an order to delivery at the destination. Electronic tracking of order fulfilment can be said to be a virtual factory production line that controls speed of work. Customers are facilitated to closely monitor the delivery route with their smartphones. They might feel wronged if they were not the first delivery made on their route, even if the food was delivered within the allocated time.

Through the app, customers can view how the courier has been evaluated previously including their average delivery time (e.g., 28 minutes per delivery), percentage of orders delivered on time (e.g., 99.08\%) and the overall satisfaction level (e.g., 95\%). Importantly, besides the quantitative measures, a wide range of evaluative comments or tags, which judge their efficiency, service attitude and appearance, are displayed and updated. Examples of "positive tags" are: "polite and enthusiastic," "clean, tidy and hygienic," and "wearing work clothes." By contrast, examples of "negative 
tags" are: "slow delivery," "poor attitude" and "difficulty communicating." In this light, customer satisfaction ratings are much wider and extensive than a five-star review. Digital platforms can "monitor and extract all the interactions" between customers and workers (Srnicek, 2017, p. 255).

The specification and "enactment of techno-normative forms of control" (Gandini, 2019, p. 1041) is impactful. Couriers must proactively ensure that they do not receive negative ratings from customers because the ratings will be fed into the overall satisfaction rating system. They seek to influence the customer evaluation mechanism to gain a competitive advantage. Lin takes care of the needs of his customers:

I would say the most important relationship in this job is with the customer. The vast majority of customers are good; it only takes one in a hundred to really bring you a problem. Sometimes people understand when it's raining outside that they can't get their delivery on time; they might even call me to let me know not to rush and take my time. Some others don't understand, they call you and push you. I will have to go off my route to accommodate these people first and give them priority so to avoid a negative rating from the customer.

During the journey, the customer can communicate with the courier at any time by calling or sending a text message via the app. This additional layer of surveillance, on top of the platform algorithm, is speeding up the entire food delivery sector.

Scripts like "enjoy your food" and "have a nice day" may not be deemed adequate for service encounters. Warm and affective behaviors, such as giving a customer a natural smile, can possibly bring a good service tag. Lin, a rate-buster, gives several examples on winning the customers' hearts:

Last month I received close to 200 positive ratings from customers. I haven't asked any of them for a positive rating. After I have delivered the food, I said, "Hello, your delivery has arrived." After he has taken it, "Your litter, can I help you to take it down for you?" This is a warm-hearted thing to do. Living up flights of stairs in an old building, especially if they have reached a certain age, I help them to take the litter out and put it in the trash, they will definitely say you are nice. Every month I receive almost 200 or more positive ratings. 
When I am delivering and I know I will be overtime and can't complete the order, I will call them in advance, there has been a delay in the road in some place. If he's a student, I will buy him a 4 yuan bottle of coke. "I'm sorry, I delayed you, please you drink a bottle of coke," he'll be happy.

The couriers are acutely aware of the impact of a complaint, which will far outweigh the costs of buying a soft drink for the customer. In trial and error, they are becoming more sensitive to managing customers' impatience, hunger and anger in delays. Proper "emotional offerings" smooth things out in the hierarchical relationships (Hochschild, [1983] 2003). Doing emotional labor, such as greetings and giving a helping hand, simultaneously generate a profit for firms.

The social process of production takes the dual forms of digital communications via the app and food delivery in actual, physical space (Gandini, 2019). Time responsiveness, friendliness and reliability in customer service (not having food and drinks spilled all over) are all important. When time is extremely tight, however, couriers cannot afford to offer extra, value-added personal service. Worse, in a society where the customer is king, they are expected to accept disrespect, even when they should not be held accountable for bad food quality or poor packaging. The burden of emotional work is shifted from platform managers and restaurants owners to workers on the frontline.

\section{Discussion and conclusion}

Meal delivery couriers are now part of the daily urban landscape. In Beijing, as in other major cities, couriers often wear company uniforms to identify themselves at work, but they are non-employees. They exercise their freedom to take leave without having to go through the bureaucratic and cumbersome procedures to seek approval from the higher-ups, which was required in their past jobs in the factory or on the construction site. During work, in between delivery rides, couriers also enjoy chatting, smoking or playing videogames while waiting for incoming orders. The ability to 
make personal decisions, such as changing the work area without losing the online work opportunity, is evident of the exercise of agency, if only to a small extent. In their multi-year study, Ping Sun and Julie Yujie Chen (2021) similarly show that younger workers pursue a freer lifestyle by logging onto one or multiple platforms as they wish, whether part-time or full-time.

The dual management strategies of algorithmic automation and customer appraisal are intended to maximize profits in the platform workspace. None of the 32 informants can fully comprehend the variable pricing mechanism, which remains highly obscured. Whereas they retain self-control over the scheduling of work, they cannot secure how much to be earned at the end of the working day. In an attempt to hit targets and henceforth the bonuses, they have lengthened their working time and intensified their labor by delivering several orders in one go. In effect, they comply with "algorithmic despotism" to serve customers around the clock (Greisbach et al., 2019).

A massive pool of on-call food-delivery workers is driving growth in a slowing Chinese economy. Workers are unable to set the price or remuneration for their services. They sell their manual and emotional labor in exchange for an unstable income. While some had made more money than before, the others unfortunately had serious injuries and quitted. With no access to subsidized health care in the city, the injured migrant workers left for their home villages altogether.

To conclude, the sense of freedom and autonomy as publicized by platform companies is severely constrained. Corporate control is tightened to entice crowdsourced workers to continue to stay online and stand by. Recent explorations of food-delivery workers' resistance to precarious working conditions, particularly at the small-scale collective level, are worthy efforts (Liu; Friedman, 2021; Lei, 2021). Yet, the individualized and atomic nature of independent service contracting remains largely unchanged. When a desperate worker set himself on fire over the protracted pay dispute in January 2021, he set a deeply disturbing precedent (Yang; McMorrow, 2021). Six months later, the Beijing leadership including the trade union federation eventually issued a set of "guiding opinions" in an attempt to strengthen 
protection for food delivery workers (Ministry of Human Resources and Social Security et al., 2021). The contestation of power between labor and capital will continue to play out in state-guided digital capitalism.

\section{Acknowledgments}

The author thanks Simon Malyon for his contribution to fieldwork and invitation to collaborate. She is also grateful to Ping Sun, Julie Yujie Chen and Amber Zhang for their coparticipation in the panel entitled "Labor and technology in China's digital transformation" in the 2018 Association for Asian Studies (AAS)-in-Asia conference in Delhi, India. In the writing process, she benefitted from helpful comments of Sociologias editors, anonymous reviewers, Rafael Grohmann, Chris K. C. Chan, Eric Florence and Jack Linchuan Qiu. Last but not least, she would like to express her gratefulness to every food delivery worker who has taken the time to share their experience.

Jenny Chan is a Doctor of Philosophy, assistant professor of Sociology at the Hong Kong Polytechnic University, and vice president of the International Sociological Association's Research Committee on Labour Movements. $\bowtie$ jenny.wl.chan@polyu.edu.hk

\section{References}

1. BARRATT, Tom; GOODS, Caleb; VEEN, Alex. "I'm my own boss. . .": active intermediation and "entrepreneurial" worker agency in the Australian gigeconomy. Environment and Planning A (EPA): Economy and Space, v. 52, n. 8, p. 1643-1661, 2020. https://doi.org/10.1177\%2F0308518X20914346

2. BRAVERMAN, Harry. Labor and monopoly capital: the degradation of work in the twentieth century. 25. ed. aniv. New York: Monthly Review Press, [1974] 1998.

3. BURAWOY, Michael. The politics of production: factory regimes under capitalism and socialism. London: Verso, 1985. 
4. BURAWOY, Michael. Manufacturing consent: changes in the labor process under monopoly capitalism. Chicago: University of Chicago Press, 1979.

5. CANT, Callum; MOGNO, Clara. Platform workers of the world, unite! The emergence of the Transnational Federation of Couriers. The South Atlantic Quarterly, v. 119, n. 2, p. 401-411, 2020. https://doi.org/10.1215/00382876-8177971

6. CHEN, Julie Y.; SUN, Ping. Temporal arbitrage, fragmented rush, and opportunistic behaviors: The labor politics of time in the platform economy. New Media \& Society, v. 22, n. 9, p. 1561-1579, 2020. https://doi. org/10.1177\%2F1461444820913567

7. FULLER, Linda; SMITH Vicki. Consumers' reports: management by customers in a changing economy. Work, Employment \& Society, v. 5, n. 1, p. 1-16, 1991. https://doi.org/10.1177\%2F0950017091005001002

8. GALLAGHER, Mary E. Can China achieve inclusive urbanization? In: FINGAR, Thomas; OI, Jean C. Fateful decisions: Choices that will shape China's future. Palo Alto: Stanford University Press, 2020. p. 180-99.

9. GANDINI, Alessandro. Labour process theory and the gig economy. Human Relations, v. 72, n. 6, p. 1039-56, 2019. https://doi. org/10.1177\%2F0018726718790002

10. GRIESBACH, Kathleen; REICH, Adam; ELLIOT-NEGRI, Luke; MILKMAN, Ruth. Algorithmic control in platform food delivery work. Socius: Sociological Research for a Dynamic World, v. 5, p. 1-15, 2019. https://doi. org/10.1177\%2F2378023119870041

11. HEEKS, Richard. Decent work and the digital gig economy: a developing country perspective on employment impacts and standards in online outsourcing, crowdwork, etc. Centre for Development Informatics, University of Manchester. Working Paper n. 71, 2017.

12. HOCHSCHILD, Arlie R. The managed heart: commercialization of human feeling. 20th Anniversary Edition. Berkeley: University of California Press, [1983] 2003.

13. IVANOVA, Mirela; BRONOWICKA, Joanna; KOCHER, Eva; DEGNER, Anne. The app as a boss? Control and autonomy in application-based management. Arbeit | Grenze | Fluss - Work in Progress interdisziplinärer Arbeitsforschung, n. 2, 2018, Frankfurt (Oder): Viadrina, https://doi.org/10.11584/arbeit-grenze-fluss.2

14. LEE, Ching Kwan. China's Precariats. Globalizations, v. 16, n. 2, p. 137-154, 2019. https://doi.org/10.1080/14747731.2018.1479015

15. LEE, Min Kyung; KUSBIT, Daniel; METSKY, Evan; DABBISH, Laura. Working with machines: The impact of algorithmic, data-driven management on human workers. In: Annual ACM Conference on Human Factors in Computing Systems, 33, Seoul, 2015. Proceedings [...]. New York: Association for Computing Machinery, 2015. p. 1603-1612. https://doi.org/10.1145/2702123.2702548

16. LEI, Ya-Wen. Delivering solidarity: Platform architecture and collective contention in China's platform economy. American Sociological Review, v. 86, n. 2, p. 279-309, 2021. https://doi.org/10.1177\%2F0003122420979980 
17. LEIDNER, Robin. Fast food, fast talk: Service work and the routinization of everyday life. Berkeley: University of California Press, 1993.

18. LIU, Chuxuan; FRIEDMAN, Eli. Resistance under the radar: Organization of work and collective action in China's food delivery industry. The China Journal, v. 86, n. 1, p. 68-89, 2021. https://doi.org/10.1086/714292

19. MILKMAN, Ruth; ELLIOTT-NEGRI, Luke; GRIESBACH, Kathleen; REICH, Adam. Gender, class, and the gig economy: The case of platform-based food delivery. Critical Sociology, v. 47, n. 3, p. 357-72, 2021. https://doi. org/10.1177\%2F0896920520949631

20. MINISTRY OF HUMAN RESOURCES AND SOCIAL SECURITY, THE PEOPLE'S REPUBLIC OF CHINA et al. Guiding opinions on protecting workers' labor security rights and interests in new forms of employment [In Chinese], $n$. 56. July, 2021. Available at: http://www.gov.cn/zhengce/zhengceku/2021-07/23/ content 5626761.htm

21. ROSENBLAT, Alex; STARK, Luke. Algorithmic labor and information asymmetries: A case study of Uber's drivers. International Journal of Communication, v. 10, p. 3758-84, 2016.

22. SCHOLZ, Trebor. Uberworked and underpaid: How workers are disrupting the digital economy. Cambridge: Polity Press, 2017.

23. SRNICEK, Nick. The challenges of platform capitalism: Understanding the logic of a new business model. Juncture, v. 23, n. 4, p. 254-57, 2017.

24. STATE INFORMATION CENTER. China's sharing economy development report 2020 [In Chinese]. Beijing: State Information Center, 2020. Available at: http://www.d-long.com/eWebEditor/uploadfile/2020040908560664109474.pdf

25. STATE INFORMATION CENTER. China's sharing economy development report 2019 [In Chinese]. Beijing: State Information Center, 2019. Available at: http://www.d-long.com/eWebEditor/uploadfile/2019031208275119808676.pdf

26. SUN, Ping. Your order, their labor: an exploration of algorithms and laboring on food delivery platforms in China. Chinese Journal of Communication, v. 12, n. 3, p. 308-323, 2019. https://doi.org/10.1080/17544750.2019.1583676

27. VEEN, Alex; BARRATT, Tom; GOODS, Caleb. Platform-capital's “appetite" for control: a labour process analysis of food-delivery work in Australia. Work, Employment and Society, v. 34, n. 3, p. 388-406, 2020. https://doi. org/10.1177\%2F0950017019836911

28. WANG, Zixu. In China, delivery workers struggle against a rigged system. SupChina, 20 Apr. 2021. Available at: https://supchina.com/2021/04/20/inchina-delivery-workers-struggle-against-a-rigged-system/

29. WHARTON, Amy S. The sociology of emotional labor. Annual Review of Sociology, v. 35, p. 147-65, 2009. https://doi.org/10.1146/annurevsoc-070308-115944 
30. WOODCOCK, Jamie. The algorithmic panopticon at Deliveroo: Measurement, precarity, and the illusion of control. Ephemera: Theory \& Politics in Organization, v. 30, n. 3, p. 67-95, 2020.

31. WOODCOCK, Jamie; JOHNSON, Mark R. Gamification: What it is, and how to fight it. The Sociological Review, v. 66, n. 3, p. 542-58, 2018. https://doi. org/10.1177\%2F0038026117728620

32. WU, Philip; ZHENG, Yingqin. Time is of the essence: spatiotemporalities of food delivery platform work in China. In: European Conference on Information Systems, 28, Marraquexe, 2020. Proceedings [...]. Marrakesh: HEM, 2020. p. 1-15. Available at: https://aisel.aisnet.org/ecis2020 rp/156/

33. WU, Qingjun; ZHANG, Hao; LI, Zhen; LU, Kai. Labor control in the gig economy: evidence from Uber in China. Journal of Industrial Relations, v. 61, n. 4, p. 574-596, 2019. https://doi.org/10.1177\%2F0022185619854472

34. YANG, Yuan; MCMORROW, Ryan. Chinese courier sets fire to himself in protest over unpaid Alibaba wages. Financial Times, 12 Jan. 2021. Available at: https://www.ft.com/content/d6189ee8-9aea-41dd-a412-b8daba9cacf2

Received 19 Mar. 2021.

Accepted 5 Aug. 2021. 
